\title{
Teori Motivasi, Kinerja dan Prestasi Kerja dalam Al-Quran Serta Pleksibilitas Penerapannya pada Manajemen Perbankan Islam
}

\author{
Wahyudin Maguni ${ }^{1}$ dan Haris Maupa ${ }^{2}$ \\ ${ }^{1}$ Dosen FEBI IAIN Kendari - Sulawesi Tenggara- Indonesia \\ Telp.+6285241504808 E-Mail: wmaguni@yahoo.com. \\ ${ }^{2}$ Guru Besar FEB.Universitas Hasanuddin -Indonesia \\ Telp.+6281245469389-08114444070 E-Mail: hmaupa@yahoo.co.id
}

\begin{abstract}
In principle what has been discussed by experts on the theory of Work Motivation, Performance, and Achievement, from the results of the research Journal review obtained definitions as well as indicators on each theory which is a variable that is motivation, performance and work performance, essentially there is an explanation and legal source in the Koran. This is a strengthening and meaning for these variables. This is evidence that the Koran as a divine word is the greatest source of knowledge that we can learn and understand and practice in everyday life. Developing theoretical theories such as motivation, performance and work performance, can be applied and practiced in a general organization, business environment, and included in Islamic Banking.
\end{abstract}

Motivation is the process of influencing or encouraging from outside to a person or work group in order to want to carry out something that has been determined (Samsudin, 2005: 281). Furthermore Performance is the real behavior displayed by each person as work performance produced by employees in accordance with their role in the organization. Employee performance is a very important thing in the organization's efforts to achieve its goals.

And on the next point is work achievement which is one measure of the work of a person in a company organization and becomes one of the considerations in the implementation of promotion. The achievement of one's work can be seen based on the qualifications possessed, namely skills, skills, experience and environment work (adaptability).

Keywords: Motivation, Performance, and Work Achievement in Al Quran and Flexibility of its application to Islamic Banking Institutions.

\begin{abstract}
Abstrak
Pada prinsipnya apa yang telah dibahas oleh para ahli tentang teori Motivasi, Kinerja, dan Prestasi Kerja, dari hasil review Jurnal penelitian didapatkan defenisi sekaligus indikator pada masing-masing teori yang merupakan variabel yaitu motivasi, kinerja dan prestasi kerja, pada intinya sudah terdapat penjelasan dan sumber hukumnya dalam Al-Quran. Hal ini penguatan dan pemaknaan terhadap variabel tersebut.Ini adalah bukti bahwa Al-Quran sabagai kalam Ilahi ada sumber ilmu terbesar yang dapat kita pelajari dan kita pahami dan praktekkan dalam kehidupan sehari-hari. Teori teori yang berkembang seperti motivasi, kinerja dan
\end{abstract}


prestasi kerja, dapat diterapkan dan dipraktekkan dalam lingkungan organisasi umum, bisnis, dan termasuk didalamnya Perbankan Syariah.

Motivasi adalah proses mempengaruhi atau mendorong dari luar terhadap seseorang atau kelompok kerja agar mau melaksanakan sesuatu yang telah ditetapkannya (Samsudin, 2005:281). Selanjutnya Kinerja merupakan perilaku nyata yang ditampilkan setiap orang sebagai prestasi kerja yang dihasilkan oleh pegawai sesuai dengan perannya dalam organisasi. Kinerja pegawai merupakan suatu hal yang sangat penting dalam upaya organisasi untuk mencapai tujuannya.

Dan pada Point selanjutnya adalah Prestasi kerja yang merupakan salah satu ukuran terhadap hasil kerja seseorang dalam suatu organisasi perusahaan dan menjadi salah satu bahan pertimbangan dalam pelaksanaan promosi.Prestasi kerja seseorang dapat dilihat berdasarkan oleh kualifikasi yang dimiliki, yaitu kecakapan, keterampilan, pengalaman, dan lingkungan kerja (kemampuan adaptasi).

Kata kunci: Motivasi, Kinerja, dan Prestasi Kerja dalam Al Quran dan Fleksibilitas penerapannya Pada Lembaga Perbankan Islam.

\section{A. Pendahuluan}

Sumber

$$
\text { daya }
$$

manusia mempunyai peranan dominan dalam suatu organisasi atau perusahaan termasuk Perbankan Syariah. Pada dasarnya setiap perusahaan, baik instansi pemerintah maupun swasta, bukan saja meng harapkan karyawan yang mampu, cakap dan terampil, me lainkan juga di harapkan mau bekerja giat dan berkeinginan men capai hasil kerja yang optimal. Namun, sebagai penggerak roda organisasi, karyawan juga memiliki kebutuhan, keinginan, dan dorongan yang diharapkan di peroleh dari perusahaan.

Harapan ini disebut motivasi, dimana jika harap an ini tidak terpenuhi, maka akan muncul keluhan yang lambat laun dapat meng akibatkan perusahaan stagnan, yang berdampak pada kinerja yang dihasilkan.

Selanjutnya Suatu penelitian telah memperlihatkan bahwa suatu lingkungan kerja yang menyenangkan sangat penting untuk mendorong tingkat kinerja karyawan yang paling produktif. Dalam interaksi sehari-hari, antara atasan dan bawahan, berbagai asumsi dan harapan lain muncul. Ketika atasan dan bawahan membentuk serangkaian asumsi dan harapan mereka sendiri yang sering agak berbeda, perbedaan-perbedaan ini yang akhirnya berpengaruh pada tingkat kinerja. Kinerja adalah hasil seseorang secara 
keseluruhan selama periode tertentu di dalam melaksanakan tugas, seperti standar hasil kerja, target atau sasaran atau kriteria yang telah ditentukan terlebih dahulu dan telah disepakati bersama.(Rivai \& Basri, 2004: 14 ).

Selain itu, peranan tenaga kerja suatu perusahaan sangat penting karena tenaga kerja merupakan penggerak utama atas kelancaran usaha dan kinerja perusahaan karena merupakan salah satu asset (kekayaan) perusahaan yang harus dipelihara dan dijaga dengan jalan memenuhi kebutuhan dan keinginannya.

Untuk menjaga agar karyawan tetap berkomitmen terhadap perusahaan maka perusahaan harus tetap dapat memberikan kepuasan kerja bagi para karyawan dengan berusaha senantiasa memenuhi kebutuhan karyawan baik secara finansial maupun non finansial dan disertai berbagai macam fasilitas (yang menunjang.

Pada dasarnya untuk melihat sampai sejauh mana peranan Sumber Daya Manusia dalam suatu perusahaan, maka dapat dilihat dari hasil prestasi kerja seorang karyawan yang ada dalam perusahaan tersebut. Untuk dapat melahirkan sumber daya manusia yang berkualitas tidak saja diperlukan pekerja yang handal, melainkan juga perlu suatu proses yang mendukung terwujudnya pekerja yang produktif sesuai dengan yang diharapkan.

Menurut Hasibuan (2000:93) prestasi kerja adalah sesuatu hasil kerja yang dicapai seseorang didalam melaksanakan tugas- tugas yang diberikan kepadanya yang didasarkan atas kecakapan, pengalaman, kesungguhan serta tepat waktu. Prestasi kerja ini merupakan gabungan dari tiga faktor penting, yatu kemampuan dan minat seorang pekerja, kemampuan dan menerima atas penjelasan delegasi tugas, serta peran dan tingkat motivasi seorang pekerja.

Banyak faktor yang mendorong peningkatan prestasi kerja karyawan antara lain besar kecilnya gaji, pendidikan dan latihan, disiplin, lingkungan dan iklim kerja, teknologi, manajemen, kesempatan berprestasi. Dalam hal ini termaksud dialamnya meningkatkan kinerja karyawan diperlukan perhatian terhadap faktor-faktor yang memengaruhi dan memperhatikan pula kebutuhan dari para karyawan, antara lain dengan pemberian insentif.

Adapun yang menjadi masalah 
dalam jurnal review ini adalah sebagai berikut: penerapan Teori motivasi, Kinerja dan Prestasi Kerja dalam dunia perbankan konvensional dan Islam?

\section{B. Teori Motivasi}

Motivasi dalam Islam diantaranya ialah:

1. Keinginan untuk menjalankan segala perintah dan menjauhi segala larangan Nya.

2. Semangat dalam mendalami ilmu agama.

3. Bekerja keras untuk emndapat rejeki halal yang di ridhoi Nya

4. Keinginan untuk terhindar dari sifat sifat buruk.

5. Motivasi memelihara diri dari kemusyrikan, kemunafikan, dan kekufuran, dll

Motivasi selayaknya menjurus pada hal hal yang baik, tidak sesuai jika mencari motivasi untuk hal yang tidak di ridhoi Allah, karena motivasi berarti "bergerak", gerakan tersebut harus berupa perbaikan diri dan mencapai kualitas yang lebih baik sebagai hamba Allah.

Allah senantiasa dekat dengan para hamba Nya, Allah memberi petunjuk bagi hamba Nya yang beriman pada Nya, Allah juga memerintahkan hamba Nya untuk senantiasa yakin dalam menjalani hidup dan yakin akan kehdupan di akherat nanti, QS At Taubah: 40 tentang motivasi :

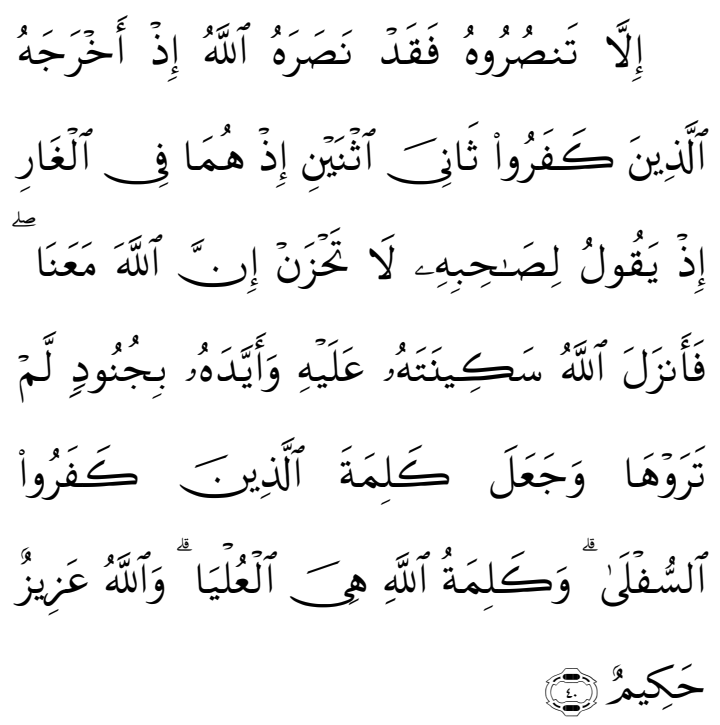

Terjemahnya: 40. Jikalau kamu tidak menolongnya (Muhammad) Maka Sesungguhnya Allah Telah menolongnya (yaitu) ketika orang-orang kafir (musyrikin Mekah) mengeluarkannya (dari Mekah) sedang dia salah seorang dari dua orang ketika keduanya berada dalam gua, di waktu dia Berkata kepada temannya: "Janganlah kamu berduka cita, Sesungguhnya Allah beserta kita." Maka Allah menurunkan keterangan-Nya kepada (Muhammad) dan membantunya dengan tentara yang kamu tidak melihatnya, dan AlQuran menjadikan orang-orang kafir Itulah yang rendah. Dan kalimat Allah Itulah yang Tinggi. Allah Maha Perkasa lagi Maha Bijaksana.

Disamping itu terdapat juga pembahasan tentang motivasi pada $\mathrm{Al}$ Quran Surah Al-Fajr ayat 27-30 yang memberikan penjelasan tentang ketenangan hati dan jiwa, sebagai 
perwujudan adanya motivasi dalam diri manusia yang selalu merasa dekat hanya kepada Allah SWT. Motivasi yang maksimal tentu akan didapatkan seorang hamba, ketika dia Menjalani semua perintah dan menjauhi larangan dari Allah SWT. Tidak ada pelanggaran, dan didalam menjalankan tugasnya sebagai hamba selalu dilaksanakan dan didasarkan pada landasan motivasi untuk beribadah dan mendapatkan ridhoNya.

QS Al Fajr: $27-30$

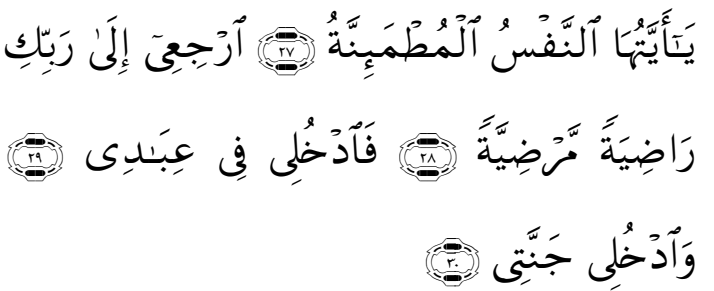

\section{Terjemahnya:}

27. Hai jiwa yang tenang.

28. Kembalilah kepada Tuhanmu dengan hati yang puas lagi diridhai-Nya.

29. Maka masuklah ke dalam jama'ah hambahamba-Ku,

30. Masuklah ke dalam syurga-Ku.

Selanjutnya dalam Al-Quran pada surah yang lain, yaitu: Q.S. At-Taubah, dengan tegas Allah SWT, memerintahkan agar hambaNya bekerja, sebagai dasar untuk mencari nafkah dan rezeki, karena Allah SWT, akan memberi bantuan kepada HambaNya yang suka bekerja, didorong dengan motivasi yang tinggi, bahwa bekerja dalam rangka untuk dapat memenuhi kebutuhan dan keinginan serta sebagai sarana untuk selalu mendekatkan diri hanya kepada Allah SWT.

QS A Taubah: 105

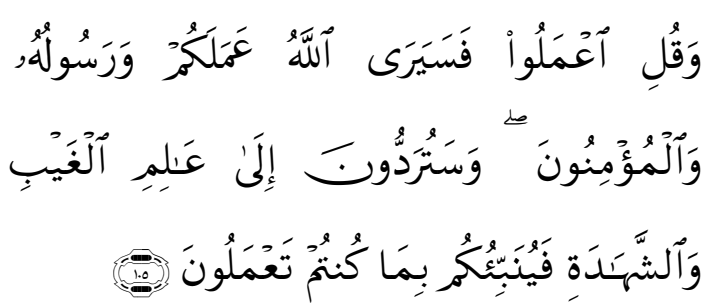

Terjemahnya: 105. Dan Katakanlah: "Bekerjalah kamu, Maka Allah dan rasul-Nya serta orang-orang mukmin akan melihat pekerjaanmu itu, dan kamu akan dikembalikan kepada (Allah) yang mengetahui akan yang ghaib dan yang nyata, lalu diberitakan-Nya kepada kamu apa yang Telah kamu kerjakan.

Seperti juga dalam Al-Quran dalam surah Al-Jumuah sangat jelas diternkan bahwa Allah SWT, sangat mewajibkan hambanya untuk menyeimbangkan antara nilai ibadah dan kegiatan muamalah, dan bekerja dalam rangka mencari rezeki yang Allah SWT sudah tebarkan diatas permukaan Bumi.Perintah bertebran diatas muka bumi ini hanya boleh dilakukan jika kewajiban kita sebagai hamba Allah sudah selasai ditunaikan, apalagi masih panjang waktu untuk mencari rezeki dari Allah pada tempat kita bekerja atau kegiatan perniagaan dan bisnis lainnya. 
QS Al Jumu'ah: 10

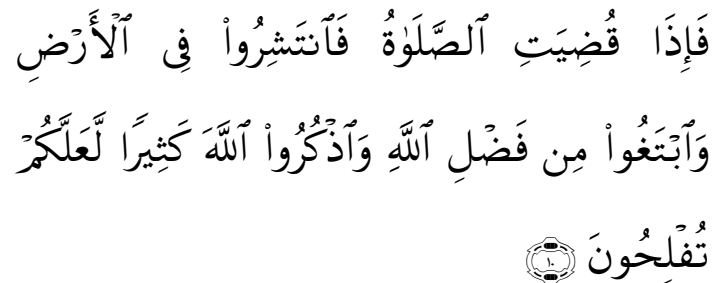

Terjemahnya: 10. Apabila Telah ditunaikan shalat, Maka bertebaranlah kamu di muka bumi; dan carilah karunia Allah dan ingatlah Allah banyak-banyak supaya kamu beruntung.

Pada prinsipnya pembahasan ayat $\mathrm{Al}$-Quran diatas terdapat secara tidak langsung pada teori-teori yang diperkenalkan oleh para ahli seperti, Hasibuan (2012:146) Merupakan dorongan kerja untuk melakukan serangkaian kegiatan yang mengarah pada tercapainya tujuan tertentu. Adapun indikatornya adalah:

Memberi kesempatan kepada pegawai untuk meningkatkan pengetahuan; (2) Mengadakan evaluasi pekerjaan secara kontinyu; (3) Membiasakan melaksanakan tugas sesuai peraturan dan ketentuan yang berlaku; (4) Memberikan kesempatan pegawai ikut serta berperan aktif dalam meningkatkan prestasi kerja; (5) Mendorong pegawai untuk meningkatkan komunikasi dan kerjasama; (6) Mendorong pegawai dalam kerja kelompok dengan unit terkait untuk meningkatkan efektivitas kelancaran dan keberhasilan tugas; (7) Mencukupi sarana dan prasarana sesuai dengan perkembangan teknologi agar tercipta lingkungan kerja yang kooperatif; (8) Melibatkan pe- gawai dalam pengambilan keputusan melalui rapat, pertemuan, evaluasi rutin dan insidental.

Tujuan motivasi menurut Hasibuan (2012:146), yaitu: meningkatkan moral dan kepuasan kerja; (2) meningkatkan produktivitas karyawan; (3) mempertahankan kestabilan karyawan perusahaan; (4) meningkatkan kedisiplinan karyawan; (5) mengefektifkan pengadaan karyawan; (6) menciptakan suasana dan hubungan kerja yang baik; (7) meningkatkan loyalitas, kreativitas, dan partisipasi karyawan; (8) meningkatkan tingkat kesejahteraan karyawan; (9) mempertinggi rasa tanggung jawab karyawan terhadap tugas-tugasnya; (10) meningkatkan efisiensi penggunaan alat-alat dan bahan baku.

Pendapat lain motivasi adalah proses mempengaruhi atau mendorong dari luar terhadap seseorang atau kelompok kerja agar mau melaksanakan sesuatu yang telah ditetapkannya (Samsudin, 2005:281).

Menurut Chung \& Megginson dalam Gomez (2003:177) motivation is 
defined as goal directed behavior. It concerns the levelof effort one exerts in pursuing a goal it is closely related to employee satisfaction and job performance (motivasi dirumuskan sebagai perilaku yang ditujukan pada sasaran. Motivasi berkaitan dengan tingkat usaha yang dilakukan oleh seseorang dalam mengejar suatu tujuan motivasi berkaitan erat dengan kepuasan pekerja dan performansi pekerjaan).

\section{Teori Kinerja}

Langkah awal terbaik yang sebaiknya kita lakukan, baik sebagai pekerja, pebinis, maupun sebagai pribadi, adalah melakukan penilaian terhadap diri sendiri (self-assesment). Mengapa kita harus melakukan penilaian kinerja diri, baik sebagai hamba maupun sebagai pekerja? Karena Allah menyuruh kita untuk melakukan hal itu. Allah berfirman dalam QS 9: 105:

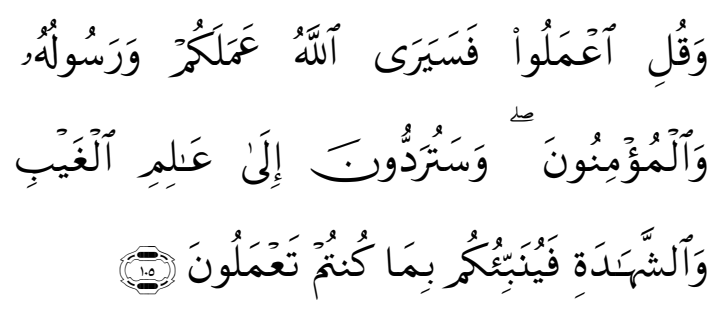

Terjemahnya: 105. Dan Katakanlah: "Bekerjalah kamu, Maka Allah dan rasul-Nya serta orang-orang mukmin akan melihat pekerjaanmu itu, dan kamu akan dikembalikan kepada (Allah) yang mengetahui akan yang ghaib dan yang nyata, lalu diberitakan-Nya kepada kamu apa yang Telah kamu kerjakan.

Kata “amalakum”berarti amalmu atau pekerjaan. Kata ini bisa berarti "amalan di dunia yakni berupa prestasi selama di dunia". Dalam bahasa manajemen, hasil dari amalan atau pekerjaan itu adalah kinerja, performance. Jadi, ungkapan "sayarallâhu 'amalakum wa rasûluhû wal mu'minûn" sejatinya adalah pelaksanaan performance appraisal. Yang perlu diperhatikan, pengungkapan kata "Allah, Rasul, dan Mukmin" (yang dalam bahasa Arab menggunakan i'rab rafa', sebagai subjek), berarti para penilai itu tidak saja Allah, tetapi juga melibatkan pihak lain, yakni Rasul dan kaum Mukmin.

Dalam bahasa manajemen, penilaian melibatkan pihak lain ini biasa disebut penilaian 3600 degree. Performance appraisal is the process of evaluating employees' performance (e.g., behaviors) on the job. A systematic review of an individual employee's performance on the job which is used to evaluate the effectiveness of his or her work (Muchinsky, 1993). Evaluasi formal dan sistematis tentang seberapa baik seseorang melakukan tugas dan 
memenuhi peran dalam organisasi (Bittel, 1996).

Penilaian kinerja juga bisa diartikan sebagai "proses organisasi yang mengevaluasi prestasi kerja karyawan terhadap pekerjaannya" (Blanchard dan Spencer, 1982). Kinerja (performance) "perwujudan dari bakat dan kemampuan (capability); atau hasil nyata dari kompetensi seseorang; dari sisi jabatan" hasil yang dicapai karena fungsi jabatan tertentu pada periode waktu tertentu (Kane, 1986: 237). Kinerja "perkalian antara kapasitas dan motivasi (Muhammad Arifin, 2004). Mengapa organisasi harus melakukan performance appraisal.

Kinerja merupakan tindakantindakan atau pelaksanaan tugas yang telah diselesaikan oleh seseorang dalam kurun waktu tertentu dan dapat diukur. Adapun indikatornya adalah: Bernardian dan Russell dalam Sedarmayanti (2008:260) (1) Tanggung jawab terhadap kualitas hasil kerja; (2) Tanggung jawab terhadap kuantitas kerja hasil kerja; (3) Penghematan waktu kerja; (4) Adanya tanggung jawab dalam mencapai tujuan organisasi; (5) Kerjasama melaksanakan tugas; (6) Kemampuan menghadapi kesulitan dalam menyelesaikan pekerjaan; (7) Koordinasi setiap tugas/pekerjaan.
Lebih lanjut Bernardian dan Russell dalam Sedarmayanti (2008:260) kinerja (performance) is defined as the record of outcomes produced on a specific job function or activity during a specific time period (kinerja didefinisikan sebagai catatan mengenai outcome yang dihasilkan dari suatu aktivitas tertentu selama kurun waktu tertentu pula).

Berdasarkan uraian yang telah disampaikan dan pendapat beberapa ahli seperti Bernardian dan Russell dalam Sedarmayanti (2008:260), Veithzal dan Ella (2009:548) dan Mahsun (2006:25) dapat disimpulkan bahwa yang dimaksud kinerja adalah adalah hasil kerja yang dapat dicapai oleh pegawai dalam suatu organisasi sesuai dengan wewenang dan tanggungjawab masing-masing dalam rangka upaya mencapai tujuan organisasi bersangkutan secara legal, tidak melanggar hukum dan sesuai dengan moral maupun etika.

D. Keuntungan dan kerugian evaluasi kinerja pegawai Menurut Mangkunegara (2007:22) keuntungan evaluasi kinerja pegawai adalah: 
1. Mempermudah hubungan antara tujuan perorangan dan tujuan unit kerja.

2. Mengurangi

ketidaksepakatan

terjadinya

pertemuan evaluasi berjalan

sesuai proses perencanaan kinerja.

3. Lebih menempatkan pimpinan dan pegawai dipihak yang sama, tidak seperti sistem penilaian maupun peringkat

4. Merupakan

pendekatan terhadap evaluasi kinerja yang paling mudah dibela secara umum.

Menurut Mangkunegara (2007:22) kerugian evaluasi kinerja adalah:

1. Menekan waktu yang relatif banyak karena perlunya menginvestasikan waktu di muka untuk melakukan perencanaan kerja.

2. Meminta pimpinan dan pegawai mengembangkan keahlian dalam menuliskan tujuan serta standar yang penting dan dapat diukur.

3. Dapat menimbulkan lebih banyak pekerjaan administrasi ketimbang sistem penilaian maupun system peringkat.
4. Dapat disalahgunakan atau digunakan sambil lalu saja oleh para pimpinan.

\section{E. Prestasi Kerja}

Sifat rajin dan bekerja keras dapat mendorong untuk berprestasi tidak harus menimbulkan dampak negatif. Oleh sebab itu, diperlukan sebuah mekanisme yang baik dalam mengatasi dampak negatif tersebut.

Mekanisme ini dapat diperoleh dari dalam Alquran. Kebutuhan berprestasi menurut Alquran bersifat duniawi dan ukhrawi yang tidak berorientasi pada kepentingan diri sendiri, tetapi kepada Allah. Dalam Islam, orang bekerja bukan untuk mencari pengakuan dari orang lain terhadap prestasi yang dibuatnya, tetapi yang dicari dalam bekerja adalah pengakuan dari Allah.

Hal ini telah dijelaskan dalam Alquran surah Alam NasyahQ.S:94 ayat 7-8

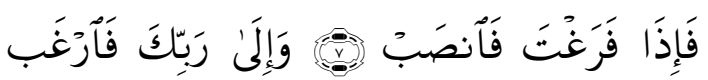

Terjemahnya: 7.Maka apabila kamu Telah selesai (dari sesuatu urusan), kerjakanlah dengan sungguh-sungguh (urusan) yang lain, 8. Dan Hanya kepada Tuhanmulah hendaknya kamu berharap. 
Ayat di atas mengandung arti bahwa seseorang harus terus bekerja dengan kesungguhan hati untuk meningkatkan prestasi. Bekerja tidak hanya sebagai suatu beban, namun setelah bekerja keras harus menikmati hasilnya dengan bergembira dan bersyukur atas pemberian Allah. Dalam bekerja, seorang Muslim harus mengharapkan pengakuan dari Allah bukan pengakuan dari sesama manusia. Bekerja karena Allah dapat melahirkan kepuasan jiwa.

Menurut Heidrahman dan Suad Husnan (1990:126), faktor-faktor prestasi kerja yang perlu di nilai adalah sebagai berikut:

1. Kuantitas kerja

Banyaknya hasil kerja sesuai dengan waktu kerja yang ada, yang perlu diperhatikan bukan hasil rutin tetapi seberapa cepat pekerjaan dapat diselesaikan.

2. Kualitas kerja

Mutu hasil kerja yang didasarkan pada standar yang ditetapkan. Biasanya diukur melalui ketepatan, ketelitian, keterampilan, kebersihan kerja.

3. Keandalan

Dapat atau tidaknya karyawan diandalkan adalah kemampuan memenuhi atau mengikuti intruksi, inisiatif, hati- hati, kerajinan dan kerja sama.

4. Inisiatif

Kemampuan mengenali masalah dan mengambil tindakan korektif, memberikan saran-saran untuk peningkatan dan menerima tanggung jawab menyelesaikan.

5. Kerajinan

Kesediaan melakukan tugas tanpa adanya paksaan dan juga yang bersifat rutin.

6. Sikap

Perilaku karyawan terhadap perusahaan atau atasan atau teman kerja Keberadaan karyawan di tempat kerja untuk bekerja sesuai dengan waktu/jam kerja yang telah ditentukan.

Prestasi kerja merupakan salah satu ukuran terhadap hasil kerja seseorang dalam suatu organisasi perusahaan dan menjadi salah satu bahan pertimbangan dalam pelaksanaan promosi.prestasi kerja seseorang dapat dilihat berdasarkan oleh kualifikasi yang dimiliki, yaitu kecakapan, keterampilan, pengalaman, dan lingkungan kerja (kemampuan adaptasi). Seluruh komponen tersebut merupakan indikator yang membantu perusahaan dalam mendapatkan tenaga kerja yang baik dan dibutuhkan sesuai 
dengan jabatan untuk mencapai tujuan perusahaan.

Berikut ini adalah indikator prestasi kerja yang menjadi bahan penelitian penulis, yaitu:

1. Kecakapan

Kecakapan adalah total dari semua keahlian yang diperlukan untuk mencapai hasil kerja yang bisa dipertanggungjawabkan. Kesulitan dalam mengukur kecakapan adalah menentukan.

Namun banyak perusahaan, jenjang pendidikan dan nilai ijazah ddpakai sebagai bahan pertimbangan untuk mengukur kemampuan dan kecakapan seseorang.

2. Keterampilan

Keterampilan kerja merupakan kemahiran seseorang dalam melaksanakan pekerjaannya termasuk dalam penguasaan alat kerja. Seringkali di berbagai perusahaan, mengharapkan memiliki seorang karyawan yang mempunyai beberapa keterampilan khusus yang dimiliki sehubungan dengan tuntutan perusahaan, dimana keterampilan juga dibutuhkan dalam rangka memecahkan masalah-masalah pekerjaan.

3. Pengalaman

Pengalaman merupakan lamanya seorang karyawan bekerja pada suatu bagian tertentu. Hal tersebur dapat memberikan suatu hasil kerja yang memuaskan kepada perusahaan. Seringkali pengalaman kerja seorang karyawan dipergunakan sebagai salah satu syarat untuk kenaikan jabatan. Sebab dengan pengalaman yang lebih banyak diharapkan memiliki kemampuan yang lebih tinggi serta mempunyai ide-ide yang dapat membangun kemampuan perusahaan.

4. Lingkungan Kerja

Lingkungan kerja merupakan segala sesuatu yang ada disekitar karyawan dan dapat mempengaruhi dirinya dalam menjalankan tugastugas yang dibebankan oleh perusahaan. Untuk melaksanakan pekerjaan secara efektif dan efisiensi perlu diperhatikan faktor lingkungan kerja yang mendukung. Syarat yang umum misalnya kebersihan, ventilasi yang cukup, suhu udara di tempat kerja, dan sebagainya. Juga perlui diperhatikan faktor-faktor jaminan keamanan dan keselamatan kerja. Hal ini sangat perlu bagi perusahaan untuk menciptakan lingkungan kerja yang baik tercapainya prestasi kerja karyawan.

Setiap perusahaan pada dasarnya menginginkan dan menuntut agar 
seluruh karyawan selalu menyelesaikan pekerjaanya dengan sebaik mungkin. Namun karyawan tidak dapat diperlakukan seenaknya seperti mengunakan faktor- faktor produksi lainnya (mesin, modal, dan bahan baku). Karyawan juga harus selalu diikutsertakan dalam setiap kengiatan serta memberikan peran aktif untuk mengunakan alat-alat yang ada. Karna tanpa peran aktif karyawan alat-alat canggih yang di memiliki tidak ada artinya bagi perusahaan untuk mencapai tujuanya.

Prestasi kerja merupakan salah satu ukuran terhadap hasil kerja seseorang dalam suatu organisasi perusahaan dan menjadi salah satu bahan pertimbangan dalam pelaksanaan promosi.prestasi kerja seseorang dapat dilihat berdasarkan oleh kualifikasi yang dimiliki, yaitu kecakapan, keterampilan, pengalaman, dan lingkungan kerja (kemampuan adaptasi). Seluruh komponen tersebut merupakan indikator yang membantu perusahaan dalam mendapatkan tenaga kerja yang baik dan dibutuhkan sesuai dengan jabatan untuk mencapai tujuan perusahaan.

Berikut ini adalah indikator prestasi kerja yang menjadi bahan penelitian penulis, yaitu:

\section{Kecakapan}

Kecakapan adalah total dari semua keahlian yang diperlukan untuk mencapai hasil kerja yang bisa dipertanggungjawabkan. Kesulitan dalam mengukur kecakapan adalah menentukan. Namun di banyak perusahaan, jenjang pendidikan dan nilai ijazah dipakai sebagai bahan pertimbangan untuk mengukur kemampuan dan kecakapan seseorang.

2. Keterampilan

Keterampilan kerja merupakan kemahiran seseoran dalam melaksanakan pekerjaannya termasuk dalam penguasaan alat kerja. Seringkali di berbagai perusahaan, mengharapkan memiliki seorang karyawan yang mempunyai beberapa keterampilan khusus yang dimiliki sehubungan dengan tuntutan perusahaan, dimana keterampilan juga dibutuhkan dalam rangka memecahkan masalah-masalah pekerjaan.

\section{Pengalaman}

Pengalaman merupakan lamanya seorang karyawan bekerja pada suatu bagian tertentu. Hal tersebur dapat memberikan suatu hasil kerja yang memuaskan kepada perusahaan. Seringkali pengalaman kerja seorang karyawan dipergunakan sebagai salah 
satu syarat untuk kenaikan jabatan. Sebab dengan pengalaman yang lebih banyak diharapkan memiliki kemampuan yang lebih tinggi serta mempunyai ide-ide yang dapat membangun kemampuan perusahaan.

\section{Lingkungan Kerja}

Lingkungan kerja merupakan segala sesuatu yang ada disekitar karyawan dan dapat mempengaruhi dirinya dalam menjalankan tugas-tugas yang dibebankan oleh perusahaan. Untuk melaksanakan pekerjaan secara efektif dan efisiensi perlu diperhatikan faktor lingkungan kerja yang mendukung. Syarat yang umum misalnya kebersihan, ventilasi yang cukup, suhu udara di tempat kerja, dan sebagainya. Juga perlui diperhatikan faktor-faktor jaminan keamanan dan keselamatan kerja. Hal ini sangat perlu bagi perusahaan untuk menciptakan lingkungan kerja yang baik tercapainya prestasi kerja karyawan.

\section{F. Kerangka Teoritis Gabungan Tiga Variabel Teori Motivasi, Kinerja, dan Prestasi Kerja}

Berdasarkan kajian dan penjelasan ke tiga teori di atas dalam hal ini motivasi, kinerja dan prestasi kerja, maka dapat digambarkan desain hubungan antar variabel teori motivasi, kinerja dan prestasi kerja sebagai berikut:

Gambar: 1. Desain Hubungan Antar Variabel

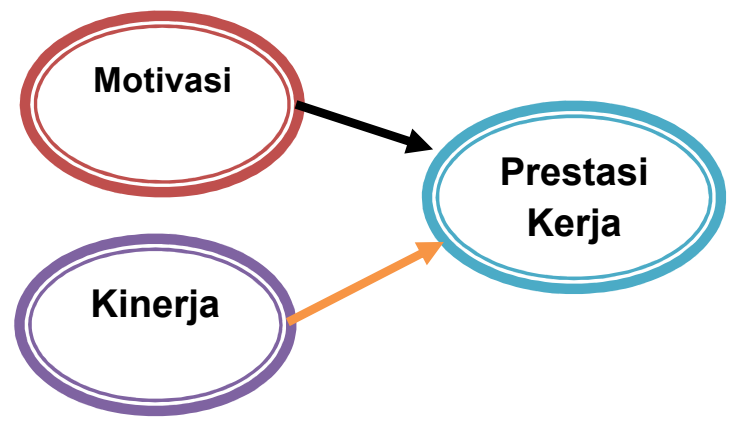

Keterangan: Hubungan Antar Variabel Motivasi, Kinerja, dan Prestasi kerja.

\section{G. Kesimpulan}

1. Pada prinsipnya Al-Quran telah memberikan penjelasan bagaimana seharusnya melaksanakan dan menerapkan motivasi, kinerja dan prestasi kerja dalam aktifitas kehidupan ,baik individu, organisasi, lembaga bisnis, dan sampai kepada organisasi jasa Perbankan dan Perbankan Syariah.

2. Jika kita melihat secara lebih obyektif bahwa variabel motivasi, kinerja dan prestasi kerja, dapat diterapkan secara serantak dan berkesinambungan pada organisasi, lembaga bisnis, dan sampai kepada organisasi jasa Perbankan dan Perbankan Syariah,dan karena pada masing- 
masing variabel tersebut mempunyai relevansi baik dalam kajian teori maupun dalam penerapan konsep dari teori motivasi, kinerja dan prestasi kerja

3. Pada teori motivasi terdapat indicator: (1) Memberi kesempatan kepada pegawai untuk meningkatkan pengetahuan; (2) Mengadakan evaluasi pekerjaan secara kontinyu; (3) Membiasakan melaksanakan tugas sesuai peraturan dan ketentuan yang berlaku; (4) Memberikan kesempatan pegawai ikut serta berperan aktif dalam meningkatkan prestasi kerja; (5) Mendorong pegawai untuk meningkatkan komunikasi dan kerja- sama; (6) Mendorong pegawai dalam kerja kelompok dengan unit terkait untuk meningkatkan efektivitas kelancaran dan keberhasilan tugas; (7) Mencukupi sarana dan prasarana sesuai dengan perkembangan teknologi agar tercipta lingkungan kerja yang kooperatif; (8) Melibatkan pegawai dalam pengambilan keputusan melalui rapat, pertemuan, evaluasi rutin dan insidental.

4. Pada teori Kinerja terdapat indikator: (l) Tanggung jawab terhadap kualitas hasil kerja; (2) Tanggung jawab terhadap kuantitas kerja hasil kerja; (3) Penghematan waktu kerja; (4) Adanya tanggung jawab dalam mencapai tujuan organisasi; (5) Kerjasama melaksanakan tugas; (6) Kemampuan menghadapi kesulitan dalam menyelesaikan pekerjaan; (7) Koordinasi setiap tugas/pekerjaan.

5. Pada Teori Prestasi kerja terdapat indikator: 1) Kuantitas Kerja.Banyaknya hasil kerja sesuai dengan waktu kerja yang ada, yang perlu diperhatikan bukan hasil rutin tetapi seberapa cepat pekerjaan dapat diselesaikan. 2) Kualitas kerja.Mutu hasil kerja yang didasarkan pada standar yang ditetapkan. Biasanya diukur melalui ketepatan, ketelitian, ketrampilan, kebersihan hasil kerja. 3) Keandalan. Dapat atau tidaknya karyawan diandalkan adalah kemampuan memenuhi atau mengikuti instruksi, inisiatif, hati-hati, kerajinan dan 
kerjasama.

4) Inisiatif

Kemampuan mengenali masalah dan mengambil tindakan korektif, memberikan saransaran untuk peningkatan dan menerima tanggung jawab menyelesaikan.5)

Kerajinan.Kesediaan melakukan tugas tanpa adanya paksaan dan juga yang bersifat rutin.6) Sikap karyawan. Perilaku terhadap organisasi, kepada atasan, dan teman kerja.7) Kehadiran. Keberadaan karyawan di tempat kerja untuk bekerja sesuai dengan waktu/jam kerja yang telah ditentukan.

\section{Daftar Pustaka}

Achmad, S. Ruki, 2001; Sistem Manajemen Kineja, Performance Management System, Panduan Praktis Untuk Merancang Kinerja Prima, Cetakan Pertama, PT.Gramedia Pustaka Utama Jakarta

Arikunto, Suharsimi. 2006. Prosedur penelitian suatu pendekatan praktek. Jakarta: Rineka Cipta.

Edwin B. Flippo dalam Marihot Tua Efendi Hariandja.2002, Manajemen sumber daya manusia Jakarta: Grasindo

Departemen Agama Republik Indonesia, Al-Qur'an dan Terjemahannya (Bandung: Sinar Baru Algesindo, 2007)
Fuad Mas'ud, (2004), Survai Diagnosis Organisasional, Badan Penerbit Universitas Diponegoro, Semarang.

Gomes, Faustino Cardoso, (2003), Manajemen Sumber Daya Manusia, Penerbit Andi,. Yogyakarta

Gouzali Saydam Manajemen sumber daya manusia, jilid 2 Jakarta, gunung agung, 1996

Handoko T. Hani. 2002. Manajemen Personalia dan Sumber Daya Manusia. Edisi II. Cetakan Keempat Belas. Yogyakarta: Penerbit BPFE.

Hasibuan, Melayu Sultan Parlaguat. 2005. Organisasi dan Motivasi: Dasar Peningkatan Produktivitas. Jakarta: Bumi Aksara.

Hasibuan, Melayu Sultan Parlagua. 2006. Manajemen - Edisi revisi. Jakarta: bumi Aksara.

Heidjrahcman Ranupandojo dan Suad Husna. 2002. Manajemen Personalia, Yokyakarta: BPFE.

Hasibuan, Melayu Sultan Parlagua. 2000. Manajemen sumber daya manusia- Edisi revisi. Jakarta: bumi Aksara.

Heidjrachman dan Suad Husnan, (1990), Manajemen Personalia, Edisi Ketiga, BPFE, Yogyakarta.

Mangkunegara, A.A. Anwar Prabu, Dr, M.SI, (2005), Evaluasi Kinerja SDM, Bandung: PT. Refika Aditama

M. Manullang, 1994 manajemen personalia. Gadjah mada university press. Yokyakarta. 
Nawawi, Hadari.H. 2001. Manajemen sumber daya manusia. Gadjah mada university press. Jakarta.

Senge, P.M. (2000). The Academy as a Learning Community: Contradiction in Terms or Realizable Future? In A.F. Lucas and
Senge, P.M. (1994). The Fifth Discipline: The Art and Practice of the Learning Organization, New York: Doubleday.

Siagian, S.P. (2002). Manajemen Sumber Daya Manusia. Jakarta: Bumi Aksara. 